Infusion Therapy

id Transfusion Medicine

Infusionstherapie

Infus Ther Transfus Med 2001;28:228-247

und Transfusionsmedizin


International Symposium, co-sponsored by

International Association for Biologicals (IABs) - Paul-Ehrlich-Institut (PEI) - Royal Society of Medicine (RSM)

\title{
International Symposium
}

\section{Advances in Transfusion Safety - 2001 June 7 to 8, 2001}

Under the patronage of the German Federal Minister of Health

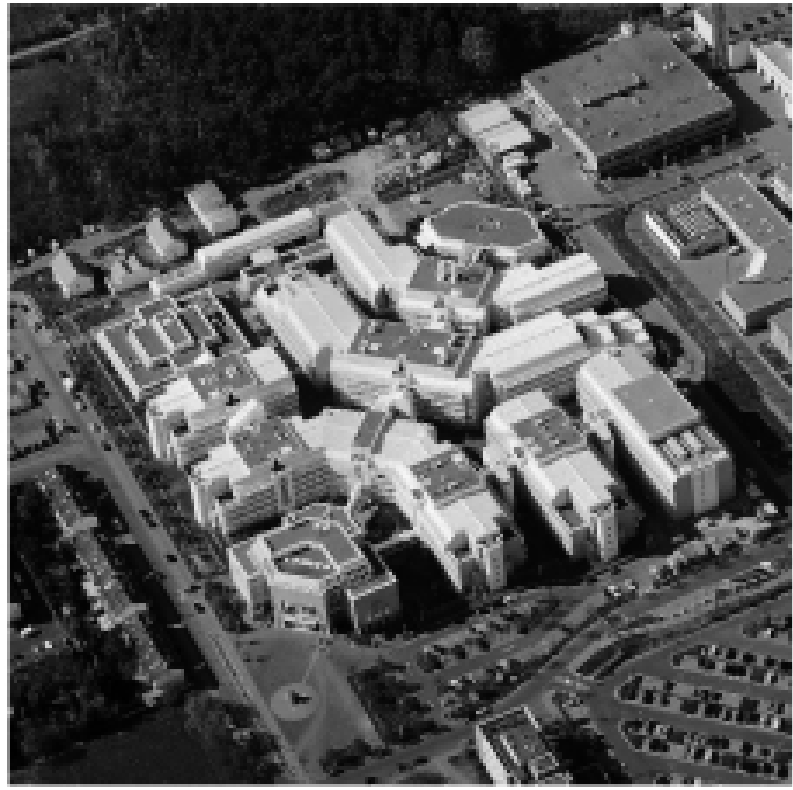

Paul-Ehrlich-Institut, Langen, Germany

\section{ABSTRACTS}

\section{Guest Editor: \\ Rainer Seitz}

\section{KARGER}

Fax +497614520714

(c) 2001 S. Karger GmbH, Freiburg

Accessible online at:

E-mail Information@Karger.de www.karger.com/journals/iut
Invited lectures will be published in:

International Association for Biologicals (IABS) (ed):

Advances in Transfusion Safety. Dev Biol. Basel, Karger, 2002 


\section{Scientific Program}

1 Safety of donors and recipients, and hemovigilance

Moderators: B. Kubanek, P. R. Ganz

$1.1 \quad$ W.H. Dzik Safety aspects in transfusion medicine

1.2 D. Rebibo Hemovigilance: French experience

1.3 W.G. van Aken Hemovigilance: View of a transfusionist

2 Trends in global epidemiology: "old" and "new" pathogens

Moderators: R. Seitz, J. C. Petricciani

$2.1 \quad$ R. Kurth New and emerging infectious diseases

2.2 P. Minor Beyond HIV, HBV and HCV: How to deal with other viruses?

3 Status of NAT screening for HCV, HIV, and HBV

Moderators: M. Nübling, G. N. Vyas

3.1 E. Seifried Experience in Germany

3.2 T. Tomono Experience in Japan

3.3 S.L. Stramer Experience in the USA

3.4 J.-P. Allain NAT screening implications: Revision of "conventional" testing?

$4 \quad$ Bacteremia: An underrated problem?

Moderators: G. Bein, G. Andreu

4.1 M.A. Blajchman

4.2 T. Montag-Lessing

4.3 M.E. Brecher

$5 \quad$ Prion diseases

$\begin{array}{ll}5.1 & \text { R.S.G. Knight } \\ 5.2 & \text { N. Hunter } \\ 5.3 & \text { F. Montrasio } \\ 5.4 & \text { D. M. Asher } \\ 5.5 & \text { H. Baron }\end{array}$

Advances in process technology

Moderators: P. Kühnl, P. Rebulla

6.1 G. Andreu

6.2 A. Farrugia

6.3 H. Willkommen

Universal leukoreduction: pro

Universal leucocyte reduction (ULR) of blood and blood products - The con case

Pathogen inactivation in human blood

$7 \quad$ Immunologic side effects

7.1 S.C. Meuer

$7.2 \quad$ G. Sher

7.3 H.S.P. Garritsen

Moderators: R. Burger, W. H. Dzik

Implications of allogeneic blood for the host immune system

Allogeneic blood as risk factor for postoperative infections

Microchimerism detection techniques

8 Special Lecture: Hematopoietic stem cells

Moderators: D. Hoelzer, J. S. Epstein

8.1 R. Storb

Perspective: Rescue enabling high-dose chemotherapy, tool for immunotherapy

Poster Viewing 


\section{ORAL PRESENTATIONS (INVITED SPEAKERS' ABSTRACTS)}

\section{1}

\section{SAFETY ASPECTS IN TRANSFUSION MEDICINE}

\section{Walter H. Dzik, MD}

Massachusetts General Hospital and Harvard Medical School 55 Fruit Street, Boston, MA 02114, USA

Safe transfusion therapy is a worldwide priority. Safe transfusion practice results from the shared responsibility of blood donors, blood collection facilities, hospital transfusion services, treating physicians and regulatory agencies. Transfusion therapy is a series of linked processes and is not simply a product. Recent decades of regulatory and scientific interest have focused on "blood safety" (safety of the product) rather than "transfusion safety" (safety of the overall process). As a result, there has been tremendous improvement in the overall safety of the products used for transfusion care. However, data from both single institution studies, from regional reporting systems, and from national hemovigilance programs all document that overall transfusion safety still has much room for improvement.

Non-infectious serious hazards of transfusion (NISHOT) represent the current greatest risk of transfusion and therefore should be the top priority for future focus of scientific and regulatory efforts. The most important NISHOT are cardio-pulmonary hazards of transfusion (including TRALI), mis-transfusion, metabolic risk of transfusion to neonates, and undertransfusion to the elderly.

Addressing NISHOT hazards will require new approaches to transfusion safety including both new professional positions (such as the Transfusion Safety Officer) and new technological solutions (such as patient transponder-based identification). In addition, a new focus on improved knowledge of the clinical indications for transfusion and computerized review of transfusion decision-making are needed. Transfusion Medicine can gain valuable insight into solutions promoting improved overall transfusion safety from the experience of nonhealth care industries such as the airline industry.

\section{3}

\section{HEMOVIGILANCE: VIEW OF A TRANSFUSIONIST}

\section{W.G.van Aken MD, PhD}

CLB/Sanquin, Amsterdam, The Netherlands

"Human error is a fact of life" (Bogner, 1994). Errors, which are defined as failures to perform an action (including inaction if required) within the tolerance limits necessary for adequate and safe performance (Kirwan 1992), are symptoms of a problem, not necessarily a cause. For many errors, finding the cause requires an overall systems view in which both the interactions among elements and the elements themselves are considered. The latter applies notably to errors in blood transfusion which may be due to each of the individual parts of the chain linking the donor to the recipient (the patient).

Hemovigilance can be defined as a set of surveillance procedures ranging from the collection of blood (components) to the follow-up of recipients, with the aim to gather and assess information on unexpected or undesirable effects resulting from the use of (labile) blood products, in order to correct their cause and to prevent their recurrence. A hemovigilance system is a national system of surveillance and alarm of such data. The concept of hemovigilance was introduced in 1992 when the health authorities in France decided to reorganise the transfusion organization. There are certain similarities with pharmacovigilance, a surveillance system required for drugs which exists already longer. Following the French initiative, transfusion organisations in other European countries such as The United Kingdom, Ireland and the Netherlands have instituted similar hemovigilance systems. In addition a rapid alert system within the European Hemovigilance Network was created to allow the quick and safe transmission of safety data. The Draft Proposal for a Directive on Blood prepared by the European Commission, which is currently discussed by the European Parliament, includes a paragraph regarding the need for hemovigilance systems.

Hemovigilance data collected during the past few years in a number of countries show that the number of incorrect blood transfusions ("wrong blood" incidents) continues to be the most frequent (up to $70 \%$ ) cause of transfusion incidents. Acute and delayed transfusion reactions, transfusion-related acute lung injury and post-transfusion purpura are significantly less frequent causes for transfusion reactions, whereas the incidence of transfusion-transmitted infections has been reported to be very low. The single most important cause of mistransfusion appears to be the failure of some aspect of the bedside checking procedure immediately prior to transfusion. Among the recommendations which have been proposed to reduce the number of transfusion incidents are the need to execute extreme care when issuing blood components and for strict adherence to guidelines at all times, education and training programs in hospitals and evaluation of computerized identification systems to ensure safe transfusion at the bedside.

\section{References}

Bogner MS. Human error in medicine. Hillsdale NJ: Lawrence Erlbaum Associates, 1994.

Kirwan B. Human error identification in human reliability assessment. Part I: Overview of approaches. Appl Ergonomics 1992;23:229-318. 


\section{THE RENAISSANCE OF OLD AND NEW PLAGES AS A CONSEQUENCE OF HUMAN BEHAVIOR}

Reinhard Kurth

Robert Koch-Institut, Nordufer 20, D-13353 Berlin, Germany

At the beginning of second half of the last century there was a widely held opinion that infectious diseases would soon lose their epidemiological relevance and clinical importance. This belief was based on the successive introduction of new antibiotics, the increasing availability of vaccines and improved public (drinking water) and individual hygiene. We now know that this opinion was grossly incorrect.

On a world-wide basis, long known and novel infectious diseases increase in prevalence and incidence. Over the last forty or so years at least thirty novel infectious diseases have been defined. In their majority, they were defined by newly detected bacteria, viruses, parasites, fungi or prions. I will delineate that in addition to the discovery of new micro-organisms it is in particular the behavior of men that allows infectious diseases to enlarge their area of geographic distribution.

The difficulties in fighting infectious diseases include the lack of vaccines against major killers (AIDS, tuberculosis, malaria), inadequate resources to use vaccines where there are most urgently needed, and risks arising from technological progress (e.g., in agriculture), changes in our environment, in our lifestyle and because of ever increasing mobility. I will illustrate various aspects by giving typical examples.

Considering evolution, it has to be recognized that only microorganisms and among them in particular the viruses are at least as successful as men. We have to take into account that micro-organisms will also vary and adept in the future. Therefore, it is in our hands whether micro-organisms will become even more successful in the future or whether they can be controlled effectively. One AIDS epidemic should have told us enough.

\section{2}

\section{BEYOND HIV, HBV AND HCV; HOW TO DEAL WITH OTHER VIRUSES?}

\section{Philip D Minor}

NIBSC, Blanche Lane, South Mimms, Potters Bar, Herts, EN6 30G, UK

Past transmission of viruses such as HBV, HIV and HCV by blood components and protein fractions are well documented and precautions based on donor selection and screening as well as processing are well established and effective. Other viruses including small non-enveloped viruses pose a greater challenge for removal, but are considered less clinically hazardous. While cell-associated viruses such as HTLVI and CMV pose a risk to certain kinds of recipients of blood components, the biggest single current issue is that of vCJD following the BSE epidemic in the United Kingdom.

\section{1 \\ STATUS OF NAT SCREENING FOR HCV, HIV AND HBV: EXPERIENCE IN GERMANY}

\section{Erhard Seifried, Walter Hitzler}

Frankfurt am Main and Mainz, Germany

Background: In Germany, HCV NAT has been mandatory since April, 1999. 43\% of the GABTS (German Association of Blood Transfusion Services) and $100 \%$ of the RCBSC (German Red Cross Blood Transfusion Service Centers) started NAT testing even before that. Altogether 2.3 and 12.7 million donations were tested by the GABTS and the RCBSC for HCV NAT, respectively. In addition, the RCBSC started a prospective multi-center study on NAT testing for HCV, HBV and HIV1 NAT in January, 1997. 10.7 million donations were tested for HBV and HIV1 NAT from 1997 through December, 2000.

Results GABTS

\begin{tabular}{|c|c|c|c|c|}
\hline & $\begin{array}{c}\text { NAT } \\
\text { only } \\
\text { positive }\end{array}$ & $\begin{array}{c}\text { Tested } \\
\text { Donations }\end{array}$ & Rate of Positives & $\begin{array}{c}\text { Prevalence } \\
\text { per Million }\end{array}$ \\
\hline HCV & $17^{1)}$ & 2.344 .030 & $1 / 137.884$ & 7.3 \\
\hline
\end{tabular}

${ }^{1)}$ To date, 3 additional NAT only positives have not yet been confirmed by seroconversion.

Results RCBSC:

\begin{tabular}{|c|c|c|c|c|}
\hline & $\begin{array}{c}\text { NAT } \\
\text { only } \\
\text { positive }\end{array}$ & $\begin{array}{c}\text { Tested } \\
\text { Donations }\end{array}$ & Rate of Positives & $\begin{array}{c}\text { Prevalence } \\
\text { per Million }\end{array}$ \\
\hline HCV & 11 & 12.731 .554 & $1 / 1.157 .414$ & 0.86 \\
\hline HIV & 1 & 10.753 .696 & $1 / 10.753 .696$ & 0.09 \\
\hline HBV & 15 & 10.758 .618 & $1 / 358.621$ & 2.79 \\
\hline
\end{tabular}


Conclusion: NAT in blood donor screening contributes to the reduction of viral transmission by transfusion of blood components. The yield of contaminated units detected in the window period corresponds to the residual risk for HCV without NAT calculated for Germany among donors of GABTS. However, the yield of contaminated units among the Red Cross donors is much smaller than estimated by theoretical calculations. The different results among the two donor populations need to be studied further. The benefit/cost ratio of NAT at the RCBSC of Germany is very low.

\section{2 \\ STATUS OF NAT SCREENING FOR HCV, HIV AND HBV: EXPERIENCE IN JAPAN}

\author{
Tsugikazu Tomono \\ Japanese Red Cross Plasma Fractionation Center, \\ 10-17 Hamamatsucho 1, Minato-ku, Tokyo 105-0013, JAPAN \\ TEL+81-3-3433-7183 ; FAX +81-3-3433-7185 ; e-mail: tomono@pfc. \\ jrc.or.jp, and the Japanese Red Cross NAT Screening Research \\ Group
}

In July 1999, we initiated NAT screening for all serologically pre-screened blood for transfusion as well as for source plasma for fractionation to assure the safety of blood and blood products. Initially, NAT was implemented for HBV, HCV and HIV-1 using 500-mini-pool samples. In order to increase the sensitivities of viral detection, thereafter, we reduced the minipool size of specimens to 50 donations.

All donated blood samples are dispatched from the blood centers to 3 NAT centers either by surface transportation or by airplane, and subjected to NAT for HBV, HCV, and HIV-1. After selecting serologically negative samples from the blood centers, 50-mini-pool specimens are made by the use of Aloka systems. Then, extraction, amplification and detection of viruses are performed using Roche's GT-12 or GTX, and ABI Prism 7700, successively. The Roche's Multiplex reagent is being used for simultaneous detection of HBV, HCV and HIV-1. The NAT results were obtained within 24 hours after donation to enable transfusion with platelet from NAT screened donations.

The $95 \%$ detection limits for each virus were as follows: 65 copies/mL or $15 \mathrm{IU} / \mathrm{mL}$ for HBV DNA ; 310 copies/mL or 74 IU/mL for HCV RNA; and 103 copies/mL or $134 \mathrm{IU} / \mathrm{mL}$ for HIV-1 RNA. Both the inhibition rate and the false-positive rate were significantly low.

During the 50-mini-pool NAT screening of all donated blood (February 1, 2000 through March 31, 2001), we have found 108 positive cases for $\mathrm{HBV}, 24$ cases for $\mathrm{HCV}$, and 4 cases for HIV-1 among 6,372,288 donations. The detection of HBV-positive donations was nearly doubled compared to the 500-minipool NAT screening. NAT for HBV could clearly detect window-donations containing $10^{2}-10^{4}$ copies $/ \mathrm{mL}$ while EIA could not detect them. For HCV, the positive rate appeared to be unchanged due to the number of pooling. Thus, window donation and late stages of viral infection could effectively be ex- cluded from transfusion by NAT of mini-pools of 50 donations simultaneously for HBV, HCV and HIV-1 using multiplex reagent. We could notify those who gave NAT-positive results to follow-up and analyze their virological and clinical status.

\section{3 \\ NAT: EXPERIENCE IN THE USA}

\section{S.L. Stramer}

American Red Cross, 9315 Gaither Road, Gaithersburg, MD, USA, 20877; 1(301)212-2801; stramers@usa.redcross.org

Nucleic acid testing (NAT) for HIV and HCV has been performed in the US since early 1999 under an investigational new drug (IND) application using pools of 16 to 24 donations and either the Gen-Probe/Chiron or Roche NAT assays. The major challenges of both NAT systems (transcription mediated amplification; TMA and PCR) are lack of automation and intra-assay contamination due to seroreactive samples contained in the same pools or runs. However, even so, the technology has worked remarkably well and the false-positive rates for NAT are comparable or lower than those for serological testing; NAT false-positive rates range from 1:20,000 to 1:40,000. During the first year of NAT in the US and Canada, the combined yield for confirmed-positive, seronegative donations has been $62 \mathrm{HCV}$ NAT-reactive donations among more than 16.3 million screened $(1: 263,000)$ and four HIV NAT-reactive donations among greater than 12.6 million screened $(1: 3,150,000)$. This yield has remained consistent during the second year of testing. The observed yield of NAT confirmed-positive donations is compatible with estimates derived form window-period projections and recent measurements of incidence. HCV yield appears to differ depending on whether HCV 2.0 or 3.0 antibody assays are used for screening. For example, over a two-year period of time, the HCV NAT yield at the ARC using HCV 3.0 has been 1:320,000 whereas for HCV 2.0 users, it has been closer to 1:150,000. Of the HCV NAT-reactive donations identified, one has not seroconverted for over a 500-day period and a second donor is approaching 300 days without seroconversion. Of donors enrolled in follow-up, the mean time to seroconversion is approximately 40 days. The predominant risk factor identified for HCV NAT-reactive donors is intraveneous drug use. NAT has also been useful when coupled with both HIV western blot and RIBA for donor counseling. Of RIBA-positives, $80 \%$ are RNA-positive with only $1 \%$ of RIBA-indeterminate and $0.1 \%$ of RIBA-negative donations testing RNA reactive. Of RIBA-positive, RNA-negatives, approximately $1 \%$ will test RNA-reactive when repeated. For HIV, $94 \%$ of western blot positives contain RNA whereas $1 \%$ of indeterminates are RNA-positive with no RNA detected in western blot-negative samples. Single donation testing will increase yield only minimally for $\mathrm{HCV}$ and due to the infrequent finding of an early HIV-infected donor, only minimally for HIV. For HBV DNA testing to be effective versus HBsAg assays, single-donation testing may be required. 
3.4

\section{NAT SCREENING IMPLICATIONS: REVISION OF "CONVENTIONAL" TESTING?}

\author{
Jean-Pierre Allain MD, PhD
}

University of Cambridge, UK

The residual risk of transfusion-transmitted viral infection in developed countries is considered minimal or negligible. Zero risk remains a strong political objective. Genomic screening for HBV, HIV and HCV represents a major advance, eliminating infectious blood donations collected during the pre-seroconversion window period, rare cases of immunosilent infections and, possibly, a large spectrum of viral variants. Since infectivity is necessarily associated with the presence of viral genome, the possible redundancy of serological screening is a legitimate issue to explore.

In HBV, HIV or HCV infections, there are antibody-positive cases without detectable viral genome. In HBV infection, up to $86 \%$ of $\mathrm{HBs} \mathrm{Ag}+$ donations are DNA+ and no evidence has been provided that DNA- donations are not infectious. There is clear evidence that blood donation anti-HBc+, as only marker of HBV, can indicate either long-term immunity or long-term carriage. In the second situation, HBV transmission by transfusion has been demonstrated without detectable viral DNA.

In HIV infection, approximately $0.6 \%$ of antibodypositive/RNA-negative individuals have been found, mostly in long-term survivor/slow progressor individuals or patients treated with highly effective drug associations (HAART). In contrast, all described cases of confirmed p24 Ag+ were HIV RNA+. Although rare, HIV-2, O and $\mathrm{N}$ are infectious and not currently detected with NAT or p24 antigen.

In HCV infection, a variable proportion of seropositive individuals seems to have recovered since viral RNA is undetectable in blood. However, the generally low level of HCV viraemia fluctuates in infected subjects and may be too low to be detectable by NAT, particularly when applied to plasma pools. In apparently recovered individuals, $\mathrm{HCV}$ genome has been found in the liver.

This data suggests that, except for HIV-1 p24 antigen, the overlap between genomic detection, positive serology and infectivity is very large, but is not complete. When both types of assay are not redundant, they both contribute, although for a small part, in insuring the safety of the blood supply. It is therefore unlikely that HBsAg, anti-HCV and anti-HIV will be discontinued when genomic screening is extended to all three viruses. HIV-1 p24 antigen screening may prove redundant with HIV-1 RNA.

For the detection of less pathogenic, intra-cellular viruses such as HTLV-I and HTLV-II, CMV and others, serological screening will remain considerably more effective than genomic testing.

\section{1 INCIDENCE AND SIGNIFICANCE OF BACTERIAL CONTAMINATION}

\author{
M. A. Blajchman, MD, FRCP(C), Professor, Pathology and \\ Medicine, \\ Dept. of Pathology, McMaster University, 1200 Main St. West, HSC- \\ 2N34, Hamilton, Ontario, Canada L8N $3 Z 5$. \\ Tel: (905) 521-2100 Ext. 76274; Fax: (905) 527-4866; \\ E-mail: blajchma@mcmaster.ca
}

Transfusion-associated sepsis (TAS) occurring during or following the transfusion of cellular blood components was one of the earliest recognized complications of allogeneic blood transfusions. The presence of bacteria in cellular blood products has been a problem for many decades and currently it likely is the most common microbiological cause of transfusion-associated morbidity and mortality. TAS due to contaminated platelet concentrates appear to be much more common than those due to red cell concentrates. The prevalence of contaminated cellular blood products (red cells and platelets) is approximately 1 in 2000; however, the transfusion to a recipient of a contaminated blood product may not be associated with morbidity. This is because many contaminated blood product units contain only few bacteria and such transfusions may be innocuous to the recipient. In other instances, contaminated blood product units may contain large numbers of virulent bacteria and endotoxins, and their transfusion may be associated with significant morbidity and may even be lethal to the recipient. The prevalence of severe episodes of TAS has not been clearly established, but is probably of the order of 1 in 50,000 for platelet units and 1 in 500,000 for red blood cell units transfused. As a result of the increased recognition that such TAS episodes can occur, a variety of measures have been proposed to try to prevent and/or control the rate of contamination of blood products.

\section{2}

\section{STERILITY TESTING OF BLOOD COMPONENTS}

\author{
T. Montag-Lessing \\ Paul Ehrlich Institute, Langen, Germany
}

In contrast to the well established awareness of virus infections, transfusion-transmitted bacterial infections have been underrated up to now. They occur with an incidence of approx. 1:10,000, life-threatening situations with an incidence of approx. 1:400,000, and fatal events must be estimated at a frequency of approx. 1:600,000 transfusions. Applying usual storage conditions, various bacteria species can proliferate in blood components up to very high germ numbers $\left(10^{8}\right.$ and more per $\mathrm{ml}$ ). Considering the intravenous application, apathogenic bacteria (e.g. propionibacteria, coagulase-negative staphylococci, environmental spore formers etc.) can lead to life-threatening states, too.

There are no universally accepted procedures regarding the surveillance of bacterial safety of blood components. In Ger- 
many, the so called "Minimal Requirements for Sterility Testing of Blood Components" were developed in 1997. Their implementation is now compulsory in all German blood facilities. (The method is available at the homepage of the Paul Ehrlich Institute under http://www.pei.de/zulass/sterimin eng.htm) The latter National Guideline considers the special instances in transfusion medicine and specifies the most important requirements concerning sterility testing of blood. Furthermore, some recommendations and comments are contained. After the implementation of the standardised method, a survey was undertaken in regard to the results of sterility control of blood components implying all blood services in Germany. Summarising the data of more than 60,000 sterility tests, a mean bacterial contamination rate of $0.19 \%$ could be determined with inconsiderable differences between the respective blood components (Platelets: $0.21 \%$; Erythrocytes: $0.17 \%$; Plasma: $0.1 \%$ ).

There are different strategies of further improving bacterial safety of blood components (e.g. platelet sterility screening and quarantine storage for two days, pre-donation sampling for removing the first volume of blood donation suspected to contain most of contaminating bacteria). The Paul Ehrlich Institute focuses its interest on the processing of a universal detection method for bacteria based on amplification of highly conserved 16 s RNA sequences and, furthermore, on the pathogen inactivation methods. As an important prerequisite, our group processed defined, cryopreserved bacteria standards for contamination experiments. The standards contain only intact living cells and are not contaminated by dead cells or products of cytolysis which could impair the results of detection or inactivation methods.

\section{1}

\section{EPIDEMIOLOGY OF vCJD}

\section{Richard Knight}

National CJD Surveillance Unit, Western General Hospital, Edinburgh, EH4 2XU,UK

Phone: 0131537 3108, Fax: 01313431404

Email: R.Knight@ed.ac.uk

Variant CJD (vCJD), first described in 1996, is believed to be due to the BSE agent, transmitted to humans from cattle probably via diet.

Currently, 97 cases have been confirmed in the UK, with 3 cases in France and 1 in the Republic of Ireland. Predictions of the final number of dietary cases in the UK and in other countries are subject to great uncertainty.

There has been concern over the possible secondary, iatrogenic, spread of vCJD, including possible risk from blood and blood products.

Experimental evidence concerning the risk of CJD infectivity in blood is potentially concerning, but epidemiological evidence provides a more relevant assessment of risk from ordinary medical practice. The following areas will be reviewed:
- The general background epidemiology of vCJD.

- The available epidemiological evidence concerning CJD risk from blood and blood products. This includes anecdotal reports, Surveillance System data, the results of Case/Control studies and 'Look-Back' studies. These data largely concern Sporadic CJD and vCJD may behave differently.

- The UK Transfusion Medicine Epidemiological Review study, which is attempting to examine any possible CJD connection between donors and recipients.

The risk of vCJD transmission via blood and blood products is, at present, theoretical. However, concern has led to a number of precautionary measures being taken in various countries.

\section{2}

\section{EVIDENCE FROM SHEEP EXPERIMENTS}

\section{N Hunter and F Houston}

Institute for Animal Health, Neuropathogenesis Unit, West Mains Road, Edinburgh EH9 3JF, Scotland, UK

We have shown that it is possible to transmit BSE to a sheep by transfusion with whole blood taken from another sheep during the pre-clinical phase of an experimental BSE infection when the donor animal appears healthy. BSE and vCJD in humans are caused by the same infectious agent and the sheep-BSE experimental model has similar pathogenesis, with involvement of the lymphoreticular system, to that of human vCJD. Although we have had only one case of positive transmission of BSE out of a total of 21 transfusions, our studies remain incomplete and further cases could occur. Our studies however reinforce the possibility that blood donated by preclinical vCJD-infected humans may represent a risk of spread of vCJD infection amongst the human population of the UK.

\section{3 PERIPHERAL PRION PATHOGENESIS: THE ROLE OF THE IMMUNE SYSTEM}

\author{
F. Montrasio ${ }^{1}$, M. Prinz ${ }^{1}$, M. A. Klein ${ }^{1}$, M. Glatzel ${ }^{1}$, \\ P. Käser ${ }^{1}$, F. Heppner ${ }^{1}$, R. Frigg ${ }^{1}$, C. Weissmann ${ }^{2}$ and \\ A. Aguzzi ${ }^{1}$ \\ ${ }^{1}$ Institute of Neuropathology, Department of Pathology, University \\ of Zürich, Schmelzbergstrasse 12, CH-8091 Zürich, Switzerland \\ ${ }^{2}$ Imperial College School of Medicine at St. Mary's, MRC Prion \\ Unit, Norfolk Place, London W2 1PG, United Kingdom
}

In prion infections, the first phase of prion replication takes place primarily in the lymphoreticular system. The identification of the immune cells actively involved in this phase is essential for deciphering the mechanisms of prion peripheral pathogenesis. Furthermore, lymphoinvasion most likely plays 
an important role in the pathogenesis of vCJD, since prion infectivity can be detected in tonsils, spleen, and appendix of vCJD patients. By understanding these mechanisms, it might be possible to develop post-exposure prophylaxis.

Replication of the scrapie agent in lymphoid tissues depends on the maintenance of normal lymphoid structure, the presence of mature B lymphocytes being essential. In spleens of wild-type mice inoculated intraperitoneally (i.p.), infectivity is associated with B and T lymphocytes as well as with the stroma, but not with the pulp-derived non-B, non-T cell fraction or with circulating lymphocytes. Infectivity in the stroma is thought to reside in radiation-resistant, prion protein $(\mathrm{PrP})$ expressing postmitotic cells. A prime candidate is the follicular dendritic cell (FDC), because the pathological isoform of the prion protein, $\mathrm{PrP}^{\mathrm{Sc}}$, colocalizes with FDCs and because chimeric mice harboring PrP-expressing but not PrP-deficient FDCs propagate prions after i.p. inoculation. Formation and maintenance of mature FDCs require the presence of B cells expressing membrane-bound lymphotoxin- $\alpha / \beta$ and activation of the TNF receptor pathway. In our experiments we studied the role of FDCs, of the TNFR/LT $\beta$ R signal pathways and of the complement components in peripheral prion pathogenesis. A summary of the results will be presented.

\section{4}

\section{UPCOMING DIAGNOSTIC TESTS FOR TRANSMISSI- BLE SPONGIFORM ENCEPHALOPATHIES (TSES)}

\section{David M. Asher, MD}

Office of Blood Research \& Review, Center for Biologics Evaluation \& Research, FDA, Rockville MD 20852-1448, USA

To reduce the remote likelihood of transmitting CJD through blood products, FDA recommends deferring donors at increased risk. The policy defers many donors who will not get CJD and fails to eliminate donors destined to get sporadic CJD. It would be better if blood could be tested for TSE agents or, failing that, to defer only those rare blood donors who have actually been infected. Potentially useful TSE tests fall into three general categories:

\section{1) Detection of infectivity.}

All successful infectivity assays for TSE agents require inoculation of animals. Cell cultures are insufficiently sensitive and do not develop identifiable cytopathic effects when infected. It is likely that lines of transgenic mice expressing prion-proteinencoding genes of other species will become the assay animals of choice, but their sensitivity to infection with a variety of human CJD strains remains to be validated and compared with that of primates. Infectivity assays show little promise for screening blood donors.

\section{2) Detection of abnormal forms of the prion protein.}

These tests are based on the finding the abnormal prion protein $\left(\mathrm{PrP}^{\mathrm{Sc}}\right)$ that consistently co-purifies with infectivity and shares many if not all of its properties. Methods to detect $\mathrm{PrPSc}^{\mathrm{Sc}}$ in brain tissues with labeled antibodies improved diagnosis of TSEs. However, current tests for PrP remaining after protease digestion are too insensitive to detect the small amounts of TSE infectivity found in blood of rodents and postulated for human blood. Newer tests, such as a dissociationenhanced fluoroimmunoassay and conformation-dependent immunoassay, measure increase in soluble PrP after treatment of $\mathrm{PrP}^{\mathrm{Sc}}$ with guanidine and may be more sensitive. The techniques should be validated with blood. New monoclonal antibodies, protocadherin 2 and plasminogen should also be tried in attempts to improve detection of $\mathrm{PrP}^{\mathrm{Sc}}$.

\section{3) "Surrogate" tests for TSEs.}

Magnetic-resonance imaging and measurement of 14-3-3 protein or other brain proteins in spinal fluid aid ante-mortem diagnosis without detecting infectivity or $\mathrm{PrPSc}^{\mathrm{Sc}}$. Such tests, however useful clinically, show little promise for screening blood donors. A recent report described reduction in an erythroidassociated mRNA in animals with TSEs that, if confirmed for humans, might be developed for donor screening.

For the moment, screening of donors by history and deferral remains the only practical way to reduce the theoretical risk of transmitting CJD by blood.

\section{5 \\ RESEARCH STRATEGIES FOR EVALUATION OF PRION PARTITIONING IN PLASMA FRACTIONA- TION: IMPACT OF DIFFERENT FORMS OF PRION SPIKE ON PARTITIONING BEHAVIOR}

\section{H. Baron}

Aventis Behring, 46 Quai de la Rapée 75601 Paris Cedex 12, France Tel. 33155715709 / Fax 33155715710

Email: henry.baron@aventis.com

Uncertainty about the presence of prions in the plasma of $\mathrm{CJD} / \mathrm{vCJD}$ patients, or of persons in the incubation phase of $\mathrm{CJD} / \mathrm{vCJD}$, has given rise to concerns regarding the safety of products derived from human plasma. Such products include coagulation factor concentrates, immunoglobulin preparations, albumins and fibrin sealants. Despite no evidence of prion transmission through plasma derivatives, regulatory authorities consider that there is a "theoretical risk" for such transmissions to occur, and that appropriate measures should be adopted to address it. These include exclusion criteria for source plasma, donor deferral criteria and quarantine/withdrawal policies. In addition, validation of manufacturing processes for prion clearance is another approach to minimize the risk of CJD transmission through purified plasma products. However, consensus on a relevant prion spiking agent for process validation which might mimic CJD prions in plasma has not been reached. To find out whether the purity of the prion spiking agent affects partitioning of prions, we evaluated the prion reduction capacities of several precipitation steps in 
the manufacture of plasma-derived products for four different prion preparations. Crude brain homogenate (minced brain), purified microsomal membranes, caveolae-like domains (CLDs) and purified, full-length $\mathrm{PrP}^{\mathrm{Sc}}$ all derived from Sc237-infected hamster brains were spiked into scaled-down production steps. The results of these studies clearly show that the three membrane-associated spikes partition differently from the purified, molecular spike in certain production steps. These results will be explored in detail during this presentation. As long as the biophysical and biochemical properties of prions in plasma have not been elucidated and characterized, prion clearance evaluation in manufacturing processes should employ several spiking agents which differ with respect to their partitioning properties, including at least one membraneassociated spike (such as microsomes) and one highly purified spike (such as purified $\mathrm{PrPSc}^{\mathrm{Sc}}$ ).

\section{2 \\ UNIVERSAL LEUCOCYTE REDUCTION (ULR) OF BLOOD AND BLOOD PRODUCTS - THE CON CASE}

\author{
Albert Farrugia \\ Head, Blood and Tissue Services, Therapeutic Goods \\ Administration Laboratories, Australian Commonwealth \\ Department of Health and Aged Care
}

Evidence-based decision making is a central principle in public health policy. In recent years, this principle has had to a assume a secondary role to the so-called "precautionary principle" in decisions related to blood safety. It is acknowledged that maintaining public confidence in the blood supply is an important outcome in health care. However, measures which compete for scarce resources must be underpinned by sound scientific principles. This common tenet between the evidencebased and precautionary approaches is frequently ignored in the search for a "zero risk" blood supply.

This presentation will contend that:

1. Despite frequent assertions to the contrary, the current "avalanche" for ULR is being driven by the risk of variant Creutzfeldt-Jakob Disease. Any evidence that such a hypothetical risk will be decreased by ULR is lacking.

2. ULR cannot be justified on standard criteria of quality, safety and efficacy which would, however, support the introduction of leucocyte reduction in certain specific situations.

3. The issue of the required level of leucocyte reduction relative to the indication it is performed for is systematically ignored. A large number of leucocyte-reduced blood components can be given in the form of non-filtered (and therefore less expensive) products.

4. The role of regulators in the current debate on ULR should be to define standards. In this regard, leucocyte reduction should be viewed as a highly manipulative manufacturing step subject to the requirements of GMP and licensure. This will result in the restriction of leucocyte re- duction to the manufacturing, rather than to the hospital, environment.

Leucocyte reduction is but one of a number of potential measures which, applied judiciously, can enhance the quality of blood transfusion therapy to patients. The introduction of ULR risks diverting resources from other measures where proven outcomes, rather than theoretical risks, are at stake.

The views of the author are not necessarily representative of the policy of the Australian government.

\section{3}

\section{PATHOGEN INACTIVATION IN HUMAN BLOOD}

\author{
Hannelore Willkommen \\ Virus Safety Section, Paul-Ehrlich-Institut, Paul-Ehrlich-Strasse \\ 51-59, D-63225 Langen, Germany; wilha@pei.de
}

Despite the increased safety of blood transfusion achieved through continued improvement of donor testing, concerns remain about the safety of blood components. Non-enveloped viruses, like HAV or parvovirus B19, which are not tested for, as well as bacteria and, under distinct conditions, also parasites may occur in blood and may be transmitted by transfusion of blood components. Several laboratories have developed procedures for the inactivation of blood cells and plasma. Such processes should have a high effectiveness for a broad range of pathogens (viruses and bacteria) and should pose no enhanced risk (e.g. toxicity, mutagenicity and carcinogenicity) for the recipients.

The presentation gives an overview about procedures that have been developed for the inactivation of blood components. They can be summarised as follows:

Photochemical methods using psoralen compounds as photosensitizers (Methoxypsoralen (8-MOP), Amino-methyltrimethylpsoralen (AMT), aminylalkylated psoralen (S-59)) and illumination with UVA $(320-400 \mathrm{~nm})$ have been developed for inactivation of platelet concentrates. The photochemical treatment can be effective for the inactivation of viruses as well as a wide range of bacteria. Conditions of treatment (plasma concentration, light exposure time, oxygen level) as well as the use of antioxidants (such as Mannitol or Rutin) influenced the stability of platelets after treatment and were most important if 8-MOP or AMT were used. S-59 is the most promising substance and phase III clinical trials with S59 treated platelets are under way.

The absorption spectrum of haemoglobin makes the use of photochemical processes for red cell inactivation difficult and particularly challenging due to the limited spectral range and to the requirement for short wave-length to achieve effective treatment. In contrast, photodynamic processes use compounds which generate active oxygen after binding and activation by illumination with cool-white fluorescence light (>600 nm). Phenothiazines (1,9-Dimethylmethylene Blue) or Phthalocyanines (Silicon Phthalocyanine, $\mathrm{Pc}_{4}$ ) are promising compounds even if their use requires antioxidants (Mannitol, 
Glutathion, Trolox, Dipyridamol) so that the functional characteristics of the red cells can be maintained under conditions being effective for pathogen inactivation. In contrast to photodynamic methods, nucleic acid targeted, non-photochemical methods relay on reactive compounds that have a high affinity for nucleic acids. Two methods have been established using the compounds Inactine and S-303.

For inactivation of plasma, the Solvent/Detergent treatment is well established. It has a high capacity for inactivation of enveloped viruses but there remains a risk for transmission of non-enveloped viruses which can contaminate the plasma to a high level (e.g. Parvovirus B19, $10^{12}$ genome equivalents/ml). Photodynamic methods utilising methylene blue (MB) as sensitiser have been developed. As MB has a low genotoxic potency, a "substance reduction device" has been developed so that $\mathrm{MB}$ and its photoproducts can be removed after treatment. Furthermore, Riboflavin and light (419 nm) are successfully used for pathogen inactivation in plasma and cells.

\section{2}

\section{ALLOGENEIC RED BLOOD CELL TRANSFUSION IS AN INDEPENDENT RISK FACTOR FOR THE DEVELOPMENT OF POSTOPERATIVE BACTERIAL INFECTION}

\author{
Hong Chang, Gregroy A. Hall, William H. Geerts, Celia \\ Greendwood, Robin S. McLeod, Graham D. Sher \\ Departments of Medicine and Surgery, The Toronto Hospital, Mt. \\ Sinai Hospital and the University of Toronto; Clinical Epidemiology \\ Unit, Samuel Lunenfeld Research Institute, and the Canadian \\ Blood Services, Toronto, Canada
}

Background and Objectives: Allogeneic red blood cell transfusions may exert immunomodulatory effects in recipients including an increased rate of postoperative bacterial infection. It is controversial whether allogeneic transfusion is an independent predictor for the development of postoperative bacterial infection.

Methods: We analysed a prospectively collected database of 1,349 patients undergoing colorectal surgery in 11 centres across Canada. The primary outcome was the development of either a postoperative wound infection or intra-abdominal sepsis in transfused and nontransfused patients. The effect of allogeneic transfusion on postoperative infection was evaluated with adjustment for all the confounding factors in a multiple regression analysis.

Results: The 282 patients who received a total of 832 allogeneic units had a significantly higher frequency of wound infections and intra-abdominal sepsis than the patients who were not transfused (25.9 vs. $14.2 \%, \mathrm{p}=0.001)$. A significant doseresponse relationship between transfusion and infection rate was demonstrated. Multiple regression analysis identified allogeneic transfusion as a statistically significant independent predictor for postoperative bacterial infection (OR 1.18, 95\% CI $1.05-1.33, \mathrm{p}=0.007)$. Other independent predictors were anastomotic leak, repeat operation, patient age and preoperative haemoglobin level. The mortality rate was also significantly higher in the transfused group.

Conclusion: These data support the hypothesis that allogeneic red cell transfusion is an independent risk factor for the development of postoperative bacterial infection in patients undergoing colorectal surgery. This association provides further reason to minimise exposure to allogeneic transfusions in the perioperative setting.

\section{3 \\ MICROCHIMERISM DETECTION TECHNIQUES}

\section{H.S.P. Garritsen}

Tissue Typing Lab. Department of Transfusion Medicine and Transplantation Immunology, University Hospital Muenster, Muenster, Germany

Techniques to evaluate the persistence of allogeneic cells after transfusion or transplantation have become an important tool to assess the results of therapeutic intervention. Established methods for determination of the grade of chimerism include red cell phenotyping, Y-chromosome specific PCR or in situ hybridisation or the use of variation in the numbers of tandem repeats (VNTR's) or short tandem repeats (STR's). Also HLA-markers are being used. The molecular tools are supposed to be the most accurate in a quantitative assessment of the chimeric status.

However, each of the above mentioned methods has its limitation in the assessment of the chimeric status of a patient. For example, Y-specific probes are only applicable if the donor is a male and the recipient a female. HLA-markers can only be used in HLA-mismatch transplantation, a situation which one mostly tries to avoid.

This presentation will review the pro and cons of the different systems for chimerism detection which are available at this moment. It will also review the possibilities of quantitative PCR methods to assess the amount of allogeneic cells.

Furthermore a new quantitative PCR method will be presented which enables one to analyze the chimeric status of all major hematologic lineages in the blood of the recipient (erythrocytes, thrombocytes and leukocytes). This method is based on the differences between mitochondrial DNA between donor and recipient and has important advantages over the methods already mentioned.

8.1 PERSPECTIVE: RESCUE ENABLING HIGH-DOSE
CHEMOTHERAPY, TOOL FOR IMMUNOTHERAPY

\section{Rainer Storb, MD}

Fred Hutchinson Cancer Research Center, Seattle, WA, USA

Traditional allogeneic hematopoietic stem cell transplantation (HSCT) for treatment of patients with hematological malig- 
nancies relies on maximally tolerated doses of systemic chemoradiation both to eradicate cancer and to achieve host immunosuppression. The allografts then serve to rescue patients from treatment-induced marrow aplasia and contribute a graft-vs.-tumor effect of uncertain magnitude. Associated toxicities have limited HSCT to younger, medically fit patients with therapy administered on specialized hospital wards. This age restriction has excluded most patients with myeloid leukemias and B cell malignancies from transplantation. To address this limitation, we have developed a nonmyeloablative transplant approach applicable to elderly or medically infirm patients in which the burden of tumor eradication has been shifted from cytotoxic agents to the graft-vs.-tumor effect. Using a large randombred canine model, we have shown that the intense conditioning regimens customarily used for host immunosuppression in HSCT could be largely replaced by optimizing postgrafting immunosuppression with a combination of mycophenolate mofetil and cyclosporine, which not only served to control serious graft-vs.-host disease (GVHD) but, as importantly, reduced the magnitude of the host-vs.graft reaction. The current clinically used conditioning regimen consists of only 2 Gy of total body irradiation (TBI) and three doses of fludarabine. The preliminary clinical results have shown the following: First, the nonmyeloablative regimen used was safe and minimally toxic. Typical side effects of conventional HSCT were not encountered. Patients did not become severely pancytopenic. As a result, $57 \%$ of eligible patients were treated entirely as outpatients, with others having relatively short hospitalizations. The need for transfusion requirements was eliminated or decreased. Second, most HLAmatched related recipients had stable engraftment despite using only 2 Gy TBI conditioning. An initially observed $20 \%$ graft rejection rate was obviated by the addition of three doses of fludarabine immediately preceding TBI. This has allowed sustained engraftment also with HLA-identical unrelated HSCT. Third, acute GVHD was seen in approximately half of the patients, though it mostly appeared to be of moderate severity. Nevertheless, we have extended the period of postgrafting immunosuppression from initially 35 days to now a minimum of 84 days after transplant in order to reduce the risk of GVHD. The optimal duration of postgrafting immunosuppression still remains to be determined. Fourth, the initially observed mixed donor-host hematopoietic chimerism was unstable in most patients, progressing to full-donor chimerism, obviating the need for DLI. Fifth, impressive antitumor responses have been seen with complete remissions in $66 \%$ of those patients who had measurable disease before transplant. Of note, accomplishment of complete remissions might take months, and in some cases, exceeded 1 year. The durability of these remissions is still unknown given that the longest followup is only $2^{1 / 4}$ years.

\section{POSTER Presentations}

\section{PREPARATION OF HIGH-PURITY AND VIRAL SAFETY PLASMINOGEN BY AFFINITY CHROMATOGRAPHY}

\author{
T.V. Danysh, Yu.V. Magerovsky, O.G. Braginetz \\ Institute of Blood Pathology and Transfusion Medicine, Lviv, \\ Ukraine,dtaras@litech.Iviv.ua
}

In the last years our laboratory has been engaged in the important problem of obtaining protein preparations with the purpose of their subsequent use both by diagnostic and medical means. For this purpose affinity sorbents on a basis of modified silica (silochrome) with use of various ligands (antibiotics-polypeptides, amino acid residues, and others) were synthesized.

We report a new method to produce a solvent/detergent-treated and pasteurized Lys-plasminogen. Plasminogen was obtained from solvent/detergent-treated supernatant (1\% $\mathrm{TNBP} / 1 \%$ Triton $\mathrm{X}-100,30^{\circ} \mathrm{C}, 1$ hour) which remained after preliminary precipitation of prothrombin complex proteins by barium citrate from plasma II+III Kohn fraction. This procedure was carried out by affinity chromatography on L-Lyssilochrome. At this stage we received a preparation with 80 to 120 -fold purification. During the chromatographic process plasminogen was adsorbed by ligand, solvent and detergent were washed away with buffer solutions. High purity plasminogen was eluted by buffer which contained $0.25 \mathrm{M} \varepsilon$ aminocaproic acid. With the purpose of increasing safety of the preparation, it was subjected to pasteurization $\left(60^{\circ} \mathrm{C}\right.$, 10 hours). For stabilization of plasminogen this stage was conducted at $\mathrm{pH} 3.0$ and in presence of $0.01 \%$ L-Lys. This procedure was followed by a gel filtration step using Toyopearl HW-40F, sterilization through Millipore filter (22-45 $\mu \mathrm{M})$ and lyophilization.

A method of quantitative determination of solvent and detergent in the researched preparations was also developed.

\section{QUALITY CONTROL OF BLOOD COMPONENT PRODUCTS BY FLOWCYTOMETRY}

\section{Beat M. Frey, Monika Furrer,}

\section{Manuel Frey-Wettstein (www.zhbsd.ch)}

Stiftung Zürcher Blutspendedienst SRK, Hirschengraben 60, $\mathrm{CH}-8001$ Zürich, Switzerland

Introduction: Blood component products (platelet concentrates (PC), red blood cell concentrates (EC) and fresh frozen plasma (FFP)) are considered pharmaceuticals and therefore must comply with stringent product specifications. Reassurance and documentation of product quality require systematic quality controls performed on an adequate number of randomly chosen products. Since the maximum number of conta- 
minating cells (rCC's) accepted is 2 to 3 log below the linearity range of cell counters, alternative methods for cell quantification are needed. Chamber counting techniques are subjective and cumbersome methods with limited throughput capacity and unsatisfactory data documentation. Therefore, we evaluated flowcytometry to overcome these hurdles.

Methods: For quantification of residual leukocytes (rWBCs), we used the LeucoCount kit from Becton Dickinson according to the manufacturer's recommendations. We validated the system by assessing dilution experiments of double leukocytefiltered ECs, FFPs and leukoreduced PCs, that were spiked with known number of WBCs. Quantification of residual erythrocytes (rRBCs) in PCs and FFPs was performed using RBC surface staining with phycoerythrin-conjugated anti-GlycophorinA antibody and TruCount tubes (Becton Dickinson) containing double-fluorescing polystyrol beads as calibrator [1]. Linearity and variability of determination as well as reproducibility of cell quantification over time were investigated. Representative samples of routine application of the methods will be provided.

Results: rWBC: Linear regression analysis of rWBC quantification compared with expected rWBC showed high correlation coefficients over the range of spikes analyzed ( 0 to 10 $\mathrm{WBC} / \mu \mathrm{l}): \mathrm{R}^{2} \mathrm{EC}=0.9950, \mathrm{R}^{2} \mathrm{PC}=0.9996, \mathrm{R}^{2} \mathrm{FFP}=0.9970$. The coefficients of variation (VC) assessing spiked EC, PC and FFP were $\mathrm{VC}_{\mathrm{EC}}=6.4 \%, \mathrm{VC}_{\mathrm{PC}}=4.7 \%$ and $\mathrm{V}_{\mathrm{FFP}}=4.0 \%$. Heavily leukodepleted, unspiked BP showed higher VC's. Throughout spike levels of 0 to $100 \mathrm{WBC} / \mu \mathrm{l}$, rWBC counts remained stable for $>7$ days, applying appropriate storage conditions of samples. However, ECs spiked with $500 \mathrm{WBCs} / \mu \mathrm{l}$ showed exponential drop-off of rWBC starting $24 \mathrm{~h}$ of sample storage. $\underline{\text { rRBCs}}$ : Measured numbers of rRBCs correlated strongly with expected rRBCs in the respective products: $\mathrm{R}^{2} \mathrm{PC}=0.9914, \mathrm{R}^{2} \mathrm{FFP}=0.9989$. Coefficients of variation were $\mathrm{VC}_{\mathrm{PC}}=3.0 \%, \mathrm{~V}_{\mathrm{FFP}}=0.7 \%$, resp. In experimental samples, VC's of rRBC quantification increased from $0.8 \%$ to $3.3 \%$ by decreasing spike levels. Over time ( $>7$ days), rRBC enumeration in $\mathrm{PC}$ and FFP remained stable at the respective spike levels tested $\left(0 \times 10^{3} \mathrm{RBC} / \mu \mathrm{l}\right.$ to $\left.10 \times 10^{3} \mathrm{RBC} / \mu \mathrm{l}\right)$.

Conclusions: 1 . Conventional flowcytometry is suitable to reliably quantify contaminating rWBCs and rRBCs in cell-depleted blood products. 2. Quantification of rCC's can be performed up to 7 days of sample preparation, if appropriate storage conditions of samples are applied. 3. Flowcytometry may allow to standardize and economize product quality control by batch analysis. 4 . Due to high throughput capacity, less investigator dependency and unrestricted data storage (list mode data) with option for reanalysis, flowcytometry may be considered as new gold standard technique for quality control of heavily leukodepleted blood products.

\section{Reference}

1 B.M. Frey, U. Minder, M. Furrer, M. Frey-Wettstein: Quantification of Residual Red Blood Cells in Platelet Concentrates and Fresh Frozen Plasma by Flowcytometry (submitted).

\section{QUANTIFICATION OF RESIDUAL RED BLOOD CELLS IN PLATELET CONCENTRATES AND FRESH FROZEN PLASMA BY FLOWCYTOMETRY}

\author{
Beat M. Frey, Ursina Minder, Monika Furrer, \\ Manuel M. Frey-Wettstein (www.zhbsd.ch) \\ Stiftung Zürcher Blutspendedienst SRK, Hirschengraben 60, \\ $\mathrm{CH}-8001$ Zürich, Switzerland
}

Introduction: Quality assurance of heavily cell-depleted blood products (BP) warrants sophisticated methods for quantification of residual cell contaminants. Measurement of residual red blood cells (rRBC) in platelet concentrates (PC) and fresh frozen plasma (FFP) requires quantification techniques that perform 2 to 3 log below linearity range of regular cell counters. Flowcytometry seems to be suitable for accurate counting of rRBCs in blood products.

Method: Based on selective and ample expression of glycophorin-A by the RBC membrane, we designed a staining protocol for RBCs in PC and FFP using a commercially available, Phycoerythrin (PE)-conjugated, anti-glycophorin-A monoclonal antibody (aGlyA-PE, murine IgG2b, clone GAR2 (HIR2), Pharmingen). Quantification of rRBCs was performed on a FACS Calibbur flowcytometer using TruCount tubes (Becton Dickinson), containing fluorescing polystyrol beads as calibrator. Briefly, aGlyA-PE first was diluted with FACSFlow $^{\mathrm{TM}}$ (pH 7.4, Becton Dickinson) containing 0.5\% BSA (bovine serum albumin) in order to eliminate agglutinating activity of the antibody but still maintaining adequate surface staining. $500 \mu \mathrm{l}$ of the stained aliquot was then used to resuspend the microbeads according to manufacturer's recommendation. Stained RBCs and reference beads were counted by flowcytometry applying specifically designed gating strategy. The RBC concentration and total amount of RBCs per unit were calculated based on known concentration of microbeads. The protocol was validated by quantifying logarithmically diluted PCs and FFPs, that have been spiked with known number of blood group identical RBCs. In addition, comparative studies using Neubauer chamber techniques were performed.

Results: The optimal dilution factor of aGlyA-PE in FACSFlow $^{\mathrm{TM}} / 0.5 \%$ BSA for use in PC and FFP was found to be 1:50 and 1:250, respectively. Prediluted aGlyA-PE proved to be stable and fully active for more than 14 days, if stored at $+4 \pm 2^{\circ} \mathrm{C}$. By linear regression analysis of spiking experiments, the quantified rRBCs in PC and FFP correlate strongly with expected numbers in the respective products $\left(\mathrm{R}^{2} \mathrm{PC}=0.9949\right.$, $\mathrm{R}^{2}$ FFP $=0.9994$ resp.). The coefficient of variation for determination of rRBCs assessing regular PC and FFP was below 5\% $\left(\mathrm{V}_{\mathrm{PC}}=3.0 \%, \mathrm{~V}_{\mathrm{FFP}}=0.7 \%\right)$. Quantification of $\mathrm{rRBCs}$ by FACS showed improved accuracy as compared to chamber technique. However, if the $\mathrm{rRBC}$ concentration is $\langle 1 \mathrm{RBC} / \mu \mathrm{l}$, alternative quantification techniques should be considered. In consecutive tests over more than 7 days, the results of rRBC quantification remained stable and accurate at spike levels of interest.

Conclusions: 1. Our protocol provides a reliable and accurate 
method for enumeration of rRBCs in blood products using conventional flowcytometry. 2. Compared with standard methods such as chamber counting, our method minimizes technician-related inaccuracy and has high throughput capacity. 3. The method allows to economize and simplify rRBC quantification by batch analysis. Together with high throughput capacity and unrestricted data availability for reanalysis, flowcytometry may become an important tool for product quality control in modern blood banking.

\section{EVALUATION OF ROBUSTNESS FOR THE SOLVENT- DETERGENT AND PASTEURISATION TREATMENTS ON DIFFERENT PLASMA PROTEINS}

\author{
H. Biescas, P. Ruiz, R. Gajardo, P. Ristol, M. Massot, \\ J.I. Jorquera \\ Research \& Development Area, Instituto Grifols, S.A. Barcelona, \\ Spain
}

Pasteurisation (heating in solution at $60^{\circ} \mathrm{C}$ for $10 \mathrm{~h}$ ) and Solvent-Detergent (SD) (TNBP $0.3 \% \mathrm{v} / \mathrm{v}+$ Tween $0.1 \% \mathrm{v} / \mathrm{v}$, for 6h) treatments are considered specific inactivation methods, both mechanisms being widely used for their recognised virucidal effectivity. To assess the robust nature of both treatments we studied the kinetics of inactivation of various enveloped viruses in laboratory "spiking" studies by the variation of relevant product and process parameters. We tested Human Immunodeficiency virus; Pseudorabies and/or Infectious Rhinotracheitis virus as model viruses for human Herpesvirus; and finally Bovine viral Diarrhoea virus and/or Sindbis as model viruses for Hepatitis $\mathrm{C}$ and $\mathrm{G}$. Four plasma-derived products were studied in the case of SD (Factor VIII, Alpha-1 proteinase inhibitor, Fibrinogen and intravenous (i.v.) Immunoglobulin) and six products for the Pasteurisation treatment: Albumin 5\% and 20\% (two different formulations of $20 \%$ Albumin), Antithrombin III (ATIII), intramuscular (i.m.) immunoglobulin and two different i.v. immunoglobulins. The influence of SD concentration was mainly evaluated at $90 \%$ of the regular concentration and far from processing limits $(50 \%, 25 \%)$. Other parameters were investigated such as total protein - from $0.5 \%$ to $1.71 \%(\mathrm{w} / \mathrm{v})-, \mathrm{pH}-$ from 4.83 to 7.56 -, temperature - from $23^{\circ} \mathrm{C}$ to $25.5^{\circ} \mathrm{C}$-, stabilisers sacharose, sorbitol - and buffers. Regarding pasteurisation, the parameters evaluated were protein, with ranges from $3.5 \%$ to $20 \%$, ionic strength and the effect of various stabilisers: Citrate for AT-III, Tryptophan and Caprylate for Albumin and sorbitol in the case of i.v and i.m. immunoglobulins.

The $90 \%$ SD concentration provided, for all enveloped viruses and in all products studied, Reduction Factors (RF) ranging from $\geq 4.0$ to $\geq 6.64 \operatorname{logs}$ with absence of residual infectivity from $0 \mathrm{~min}$ to $2 \mathrm{~h}$ of treatment. The inactivation kinetics also revealed not to be significantly affected by $\mathrm{pH}$, type of protein, concentration ranges or variations in process temperature. $50 \% \mathrm{SD}$ also revealed a high degree of virus reduction (4 to $6 \operatorname{logs}$ for all products), although the inactivation kinetics was slower. Pasteurisation treatment provided RFs from $\geq 4$ to $\geq 6 \operatorname{logs}$ with a maximum time needed to reach absence of residual infectivity of 2.5 hours. In conclusion, both methods revealed to be effective, consistent and robust for inactivating enveloped viruses in the plasma proteins investigated. The methods were able to deal with the variations processed without compromising their effectiveness since no relevant differences were observed in the overall infectivity reduction. From all these tests and from the extensive experience by many laboratories we can conclude that both treatments highly contribute to the safety of plasma derivatives. All these considerations lead to think about the possibility to reduce the workload associated to virus validation of SD and Pasteurisation for enveloped viruses, focusing the investigations on a single resistant enveloped model virus to be agreed between regulators and industry.

\section{GENERATION OF CUSTOM-DESIGNED INTERNAL CONTROLS FOR TAQMAN RT-PCR BY IN VITRO TRANSCRIPTION OF SYNTHETIC OLIGONU- CLEOTIDES}

\author{
B. Glock* ${ }^{*}$ D. Tröscher* , S.O. Rennhofer*, \\ R.B.K. Reisacher* and W.R. Mayr*,** \\ * Laboratory for Molecular Biology, Blood Donation Center of the \\ Austrian Red Cross for Vienna, Lower Austria and Burgenland, \\ Nordportalstrasse 248, A-1020 Vienna, Austria \\ **Clin. Dept. for Blood Group Serology, University of Vienna, \\ Austria
}

Background: Diagnostic NAT-assays need to be monitored by inclusion of internal controls into each reaction. Whereas the use of synthetic DNA oligonucleotides is a valuable tool for PCR applications in RT-PCR RNA molecules have to be used. To avoid in vitro mutagenesis and cloning steps, we have decided to apply in vitro transcription of synthetic oligonucleotides to generate custom-designed internal control RNA.

Material and Methods: A sequence similar to the wildtype target sequence, but containing a differing internal probe hybridization part, was designed using Primer Express software (Applied Biosystems). The resulting sequence was commercially synthesized by MWG Biotech.

Subsequently a $\mathrm{T} 7$ promotor site was incorporated into the oligonucleotide by PCR amplification using the regular reverse primer and a modified forward primer with 5 '-attachment of the $19 \mathrm{bp}$ core promotor sequence.

In vitro transcription was then performed using MAXIscript in vitro transcription kit (Ambion) on approximately $0.2 \mu \mathrm{g}$ and $1 \mu \mathrm{g}$ of the obtained double-stranded PCR product in 25 $\mu \mathrm{l}$ reaction volume for 1 hour at $37^{\circ} \mathrm{C}$, followed by removal of DNA template and unincorporated nucleotides by DNAse 1 digestion and ammonium acetate precipitation.

Results: Between 1 and $3 \mu \mathrm{g}$ of RNA product was obtained per reaction. Inclusion of appropriate amounts of internal control RNA into the Taqman assay revealed clear and reproducible results. RNA origin of the hybridization signals was proved by no RT-controls, which showed no amplification signals for the internal control. 
Conclusion: Direct in vitro transcription of synthetic oligonucleotides for generation of internal control RNA not only avoids work- and time-intensive steps like in vitro mutagenesis and cloning, but also gives better access to sequence design of the control molecule.

\section{HBV: DEVELOPMENT AND VALIDATION OF A REAL-TIME PCR ASSAY FOR NAT SCREENING OF SHORT-TERM BLOOD COMPONENTS}

\author{
B. Glock* , D. Tröscher*, S.O. Rennhofer*, \\ R.B.K. Reisacher* and W.R. Mayr*,** \\ * Laboratory for Molecular Biology, Blood Donation Center of the \\ Austrian Red Cross for Vienna, Lower Austria and Burgenland, \\ Nordportalstrasse 248, A-1020 Vienna, Austria \\ **Clin. Dept. for Blood Group Serology, University of Vienna, \\ Austria,Email: glock@redcross.or.at
}

Background: We have decided to develop a custom-designed Real Time assay for quick NAT testing of short-term blood products.

Methods: To guarantee the specificity of custom-designed primers and probe for known sequence variants, intensive checks of nucleotide data bases were carried out firstly. Extraction of samples was then carried out with Quiagen DNA Blood Mini Kit ${ }^{\mathrm{TM}}$. Amplification and detection were performed in $25 \mu$ reaction volume on an ABI Prism $7700^{\circledR} \mathrm{Se}$ quence Detection System for 50 cycles of the protocol recommended by the manufacturer.

Findings: For the extraction of nucleic acids a modified protocol was developed, which includes addition of poly A carrier DNA and a synthetic internal control (ssDNA) before the lysis step. For elution, samples were incubated at room temperature with prewarmed buffer AE.

Due to interactions between either the two hybridization probes (one dye labelled FAM, the other VIC) and/or interactions of sample components with the calibrator dye (ROX), $0.05 \%$ gelatine had to be included into the reaction mix.

No false-positive reactions could be observed in testing of more than 400 confirmed virus-negative plasma samples, Parvo B19, HCV and HIV-1-positive samples, whereas virus positivity was clearly indicated in commercial qualification panels, serial dilutions of the international standard and samples of a seroconversion panel containing variable antibody titers

Conclusion: A highly specific, sensitive and reliable but also very quick assay could be developed. Validation is ongoing to make use of it for qualitative as well as for quantitative applications.

\section{MICROBIOLOGICAL CONTAMINATION OF AUTOLOGOUS STEM CELL PRODUCTS}

\author{
A. Karakassopoulos, S. Schuler-Lüttmann, \\ G. Walther-Wenke \\ German Red Cross Blood Transfusion Service in Nordrhein- \\ Westfalen, Institute Münster; Sperlichstr. 15, D-48151 Münster; \\ Phone: 49-251-709-0
}

Autologous stem cell products are at risk of bacterial and fungal contamination during the collection procedure. Additional manipulations may increase the incidence of contamination. Because patients may be neutropenic on the day of reinfusion and are often immunosuppressed, the infusion of a contaminated stem cell product may add to the morbidity and mortality of the transplant procedure.

Potential sources of contamination for autologous stem cell products are the collection procedure, ex-vivo manipulations, bag breakage at the time of thawing and infusion and even bacteremia of the patient at the time of harvesting due to a permanent catheter or a port-a-cath catheter for drug application.

In this study, 1,264 autologous stem cell products drawn by leucapheresis from 227 patients were tested for microbiological contamination after processing performed in a laminar flow cabinet. $32(2.5 \%)$ autologous stem cell products have not been reinfused because of bacterial contamination. In these cases, predominantly coagulase-negative staphylococci (CNS) were found. CNS were also found in the blood cultures of the correspondent patients due to a permanent catheter. Without testing for microbial contamination by means of cultures of the stem cell preparations through the course of collecting and processing, it is difficult to determine the source of contamination.

Stem cell processing following collection performed in a laminar flow cabinet (airborne particulate classification, grade $\mathrm{A}$ EU Guide to GMP, ed. 01/97; Annex) placed in a laboratory of grade B seems to be the safest way of stem cell preparation.

\section{DETECTION OF BACTERIAL 16S RIBOSOMAL RNA USING NASBA-MEDIATED AMPLIFICATION COU- PLED TO AUTOMATED ELECTROCHEMILUMINES- CENT (ECL) DETECTION}

\author{
H. Klein, S.-B. Nicol, B. Hampel and \\ Th. Montag-Lessing \\ Paul-Ehrlich-Institute, Paul-Ehrlich-Str. 51-59, D-63225 Langen, \\ Germany
}

While blood components are routinely screened for virus markers, the risk of transfusion-related bacterial infection is a cause of concern to transfusion services. Unfortunately, most of the currently available methods detecting bacterial contaminations do not have the potential to be sensitive and fast enough for a routine contamination screening. Molecularbased tests involving PCR have shown usability, but they were 
specific for only particular organisms. Because of the high cellular copy number and conserved nature amplification of ribosomal RNA is an attractive alternative that offers a generic approach to bacterial detection. Using a chemiluminescencelinked universal bacterial rRNA probe, Brecher et al. (1993) found that such a probe assay could detect Staphylococcus epidermidis in concentrations as low as $10^{3}$ CFUs per $\mathrm{ml}$ in platelet concentrates. NASBA or nucleic acid sequence-based amplification is a primer-dependent isothermal amplification technology which selectively amplifies RNA in a DNA-background. Since the principle amplification product of a NASBA reaction is single-stranded RNA, amplicons can easily be identified by hybridization with ruthenium chelates-labeled oligonucleotides followed by ECL detection. We describe here the development of a universal bacteria detection assay based on the NASBA-mediated amplification of a part of the 16S rRNA molecule combined with an automated ECL detection system of the amplicons.

\section{IN-VITRO CHARACTERISTICS OF PATHOGEN INACTIVATED PLATELET CONCENTRATES USING HELINX $^{\text {TM }}$ TECHNOLOGY}

\author{
K. Janetzko, L. Corash, L. Lin, L. Flament, $\underline{H}$. Klüter \\ Institute of Transfusion Medicine and Clinical Immunology, Red \\ Cross Blood Service of Baden-Württemberg, Faculty of Clinical \\ Medicine Mannheim, University of Heidelberg, Germany; \\ Cerus Corporation, Concord, CA, USA, Baxter R\&D Europe, \\ Nivelles, Belgium
}

Background: The INTERCEPT Platelet System using Helin $x^{\mathrm{TM}}$ technology with psoralen S-59 and UVA inactivates bacteria, viruses, and leukocytes in platelet concentrates (PC). After collection, PC are mixed with S-59, which reversibly intercalates into the double-stranded region of DNA and RNA. Upon UVA illumination, S-59 reacts with nucleic acid, forming covalent monoadducts and crosslinks. While platelets, containing no nuclei, are unaffected, leukocytes and pathogens are unable to further replicate. Before transfusion, the PC are treated with an adsorption matrix, which reduces the levels of residual S-59 and unbound photoproducts.

Study design and methods: In a paired study we investigated the effect of the Helinx ${ }^{\mathrm{TM}}$ technology on platelet function over a storage period of 5 days. Double-dose apheresis PC $\left(7.0 ? 10^{11}\right.$ platelets, $\left.n=8\right)$ resuspended in $35 \%$ plasma $/ 65 \%$ platelet additive solution (PAS III) were split into two equalsize PC. One PC unit was retained as an untreated Control. The other PC unit was prepared as an INTERCEPT PC treated with $150 \mu \mathrm{M}$ S-59 and 3 Joules/cm² UVA on day 1 . Platelet function was assessed by platelet count, $\mathrm{pH}, \mathrm{LDH}$, hypotonic shock response (HSR), CD62, morphology score, and electron microscopy (EM).

Results and conclusion: After 5 days of storage, there were no statistically significant differences between the INTERCEPT $\mathrm{PC}$ and Control PC with respect to $\mathrm{pH}$ (7.0 vs 6.9), HSR (37\% vs $36 \%$ ), CD62 expression ( $29 \%$ vs $28 \%$ ), morphology score
(307 vs 301$)$, cell lysis by EM (15\% vs $14 \%)$, and platelet count $\left(868\right.$ vs $\left.900 \times 10^{9} / \mathrm{L}\right)$ because the $\mathrm{p}$ values were greater than 0.05 . LDH was increased (175 vs 104 IU/L for INTERCEPT PC vs Control PC $(\mathrm{p}<0.05)$. These results demonstrated that the in vitro quality of Helinx ${ }^{\mathrm{TM}}$ pathogen-inactivated split-dose PC did not differ significantly from Control PC over the storage period of 5 days. To evaluate the therapeutic efficacy and safety of INTERCEPT apheresis platelets a randomized, controlled clinical trial (EuroSPRITE) is currently underway in thrombocytopenic patients.

\section{QUALITY ANALYSIS OF PLASMA PRODUCTS AND DERIVATIVES BY ELECTRON SPIN RESONANCE SPECTROSCOPY (ESR)}

\author{
G. Matthes ${ }^{1}$, G. Seibt ${ }^{1}$, V. Muravsky ${ }^{1,2}$ \\ ${ }^{1}$ Medlnnovation $\mathrm{GmbH}$, ESR-Analyse-Labor, Freiheitstr. 124/126, \\ D-15745 Wildau, Germany, e-mail: medinnomms@yahoo.com, \\ Tel./Fax: +49-3375-2130-00/33; \\ ${ }^{2}$ International Shakharov Institute of Radioecology Minsk, Belarus
}

A new method for qualitative evaluation of conformation flexibility and binding characteristics of proteins by electron spin resonance spectroscopy (ESR) was developed based on a specially designed, portable ESR spectrometer with integrated software for spectra analysis. Reporter molecules (stable free radicals) make it possible to evaluate molecular structure changes of proteins.

Precise and sensitive test methods for different molecules can be developed. In a first step, qualitative changes of albumin transport and detoxification functions were analyzed in different samples. In serum and plasma samples of healthy blood and plasma donors could not be obtained any abnormalities. Fatty acid transport function of albumin in plasma products and derivatives can be influenced by various methods of plasma collection, preparation, filtration, and pathogen inactivation. Evident are changes in capacity of fatty acid binding sites and ordering changes of bounded substrates in different products (integral and real transport efficiency (ITE, RTE) is decreased by more than $30 \%$ to $70 \%$ for FFP resp. commercial albumin solutions compared to physiological values).

It was demonstrated that ESR spectroscopy can be used as a quality and in-process control test procedure for albumin-containing medical drugs or immunoglobulin. The influence of albumin pasteurization and stabilization during fractionation steps may be monitored and analyzed.

Furthermore, this ESR method has a big potential for determination of conformation changes of different proteins or proteinaceous particles.

\section{Reference}

Matthes G., A. Milyutin, V. Muravsky, G. Seibt: Verfahren zur ESR-spektroskopischen Bestimmung von Veränderungen der Transporteigenschaften des Albumins in einer albuminhaltigen Probe, ESR-Spektrometer zur Durchführung des Verfahrens und Einsatz des Verfahrens zur Diagnose und Kontrolle albuminhaltiger Präparate. Erfindungsanmeldung Deutsches Patentamt 28.02.2000 (PCT/EP01/02248). 


\section{SUCCESSFUL PERFORMANCE OF THE NEW VIRUS REMOVAL FILTER PLANOVA ${ }^{\circledR}$ 20N}

\author{
B. Metzig ${ }^{1}$, T. Sato ${ }^{1}$, S. Satoh ${ }^{2}$, \\ Asahi Kasei 1Deutschland GmbH, 2Co., Japan
}

Nanofiltration using Planova ${ }^{\circledR}$ filters during the purification of plasma-derived and biopharmaceutical proteins is known to be a validatable, robust method leading to a highly purified product with a preserved biological function and a large degree of virus and prion safety.

However, until now it was still difficult to achieve a good permeability of large proteins like Factor VIII and plasma-derived immunoglobulins and at the same time to remove small non-enveloped viruses like parvovirus and hepatitis A virus. Therefore Asahi Kasei developed the new membrane Planova $20 \mathrm{~N}$. The materials used to assemble Planova $20 \mathrm{~N}$ are the same as those of Planova $15 \mathrm{~N}$ and $35 \mathrm{~N}$. In contrast, the number of active layers is increased whereas the pore size of Planova $20 \mathrm{~N}$ is slightly larger than that of Planova $15 \mathrm{~N}$. In order to show the successful removal of different viruses, spiking experiments with subsequent single and double filtrations were performed. Furthermore the permeability of large proteins was determined.

The results of the presented studies demonstrate that Planova $20 \mathrm{~N}$ has a high potential to permeate large proteins while still being able to remove even small non-enveloped viruses to a high degree.

Practical work was done at:

Planova Plant, Nobeoka, Japan

BREFF, Inc., Maryland, USA

\section{PARVOVIRUS B19 IS SENSITIVE TO PHENO- THIAZINE DYES AND LIGHT}

\section{H. Mohr, J. Knüver-Hopf}

Blood Center of the German Red Cross, Chapters of Lower Saxony, Springe, Germany

The viral safety of therapeutic blood products is very high today but small non-enveloped viruses like parvovirus B19 (B19) represent a still unsolved problem because no routine test for their detection is in use and because they are resistant to heat or solvent/detergent treatment.

Purpose: It was investigated if B19 was influenced by photodynamic treatment using different photosensitizing agents in combination with visible and UV-A light, respectively. PCR and a cell culture-based infectivity assay were used as analytical tools.

Methods: The photosensitizers tested were the phenothiazine dyes methylene blue (MB), azure A, azure B, azure C, thionine (Th) and dimethylmethylene blue (DMMB), the polycyclic quinone hypericine (Hy) and the psoralen compounds 8methoxypsoralen (8-MOP) and aminomethyl trimethylpsoralen (AMT). Dye concentration was $1 \mu \mathrm{M}$ for the phenoth- iazine dyes, $5 \mu \mathrm{M}$ for Hy and $50 \mu \mathrm{g} / \mathrm{ml}$ (approx. $100 \mu \mathrm{M}$ ) for the psoralens. The treated sample was B19 containing human plasma. Illumination time was for up to $60 \mathrm{~min}$ using fluorescent tubes for MB, the azure dyes, DMMB and Hy, sodium lamps in the case of Th and a UVA-irradiator for 8-MOP and AMT. The region of the B19 genome which was amplified in PCR was between nt 2936 and nt 3635 (K1/K2, 700 base pairs). Cell line KU812EP6 in which B19 can be propagated was cultured in RPMI 1640 containing $10 \%$ fetal calf serum and $6 \mathrm{IU} / \mathrm{ml}$ of recombinant erythropoietin.

Results: With the exception of DMMB, all phenothiazine dyes tested in combination with light diminished the PCR signal in region $\mathrm{K} 1 / \mathrm{K} 2$ within the first $15 \mathrm{~min}$ of treatment. Treatment with $\mathrm{DMMB} /$ light, Hy/light or the psoralens in combination with UV-A did not influence the PCR-signal.

The infectivity assay confirmed that B19 was at last partially inactivated by illumination in the presence of phenothiazine dyes.

Conclusion: B19 is sensitive to photodynamic treatment with $\mathrm{MB}$, Th and other phenothiazine dyes. The other photosensitizers are tested ineffective.

\section{DEVELOPMENT OF BACTERIA STANDARDS FOR CONTAMINATION EXPERIMENTS WITH BLOOD COMPONENTS}

\author{
S.-B. Nicol, M. Fischer, B. Hampel, Th. Montag \\ Paul-Ehrlich-Institut, Paul-Ehrlich-Str. 51-59, D-63225 Langen, \\ Germany \\ nicsv@pei.de
}

In order to raise the safety of blood transfusions, several novel screening methods for bacterial contaminations of labile blood components have been described. Contamination experiments with standardized bacteria should be performed for the development of such screening procedures. It was our objective to develop an effective method for producing stable bacteria suspensions containing defined numbers of vital cells. Growth curves of different bacteria species (Escherichia coli, Klebsiella pneumoniae, Staphylococcus aureus, Propionibacterium acnes, Pseudomonas aeruginosa) were monitored. In parallel, the number of bacteria was counted at different time points. After reaching a defined value, the suspensions were conserved at $-80^{\circ} \mathrm{C}$ together with a cryostabilizer. The vitality of the cryoconserved bacteria was tested immediately after freezing and a few months later.

The method makes it possible to obtain suspensions with an exactly defined number of vital cells within a short time. These bacteria standards do not contain dead cells or lysis products and can be cryoconserved for several months without a decline in the number of living cells. 


\section{CLINICAL HIV ISOLATES: A RELEVANT AND REPRODUCIBLE MODEL FOR HIV INACTIVATION STUDIES}

\author{
Asa Ohagen, Veronica Gibaja, Saika Aytay, \\ Zhou Xiaochuan, Jeff Horrigan and Aris Lazo \\ V.I. Technologies, 134 Coolidge Avenue, Watertown, MA 02472, \\ USA
}

Laboratory strains of HIV, adapted for growth in immortalized cell lines, have been commonly used as a model for HIV in viral removal and inactivation studies. However, adaption of HIV to grow in transformed cell lines in the absence of immune pressure selects for genotypic and phenotypic variants that differ from clinical HIV isolates. For example, laboratoryadapted and clinical HIV isolates display significant differences in the sensitivity to neutralizing antibodies. Thus, it is essential to establish a model system using clinical HIV isolates produced and titrated on peripheral blood mononuclear cells (PBMC), their natural target cells.

We have developed a methodology to routinely produce and test high titers of cell-free and cell-associated clinical HIV isolates. Cell-free $\left(6.4 \pm 0.30 \log _{10} \mathrm{TCID}_{50} / \mathrm{ml} \pm \mathrm{SD}\right)$ or cell-associated $\left(5.9 \pm 0.38 \log _{10} \mathrm{TCID}_{50} / \mathrm{ml} \pm \mathrm{SD}\right)$ clinical HIV isolates were produced using PHA- and IL-2-stimulated PBMC. Infectious titers were determined using PBMC as indicator cells and the infectivity was monitored by the release of HIV p24 proteins into the cell medium up to 21 days p.i. to both increase the sensitivity of the assay and to avoid under-estimating residual virus infectivity.

This new model system was used to study the inactivation efficacy of the INACTINE ${ }^{\mathrm{TM}}$ compound PEN110 on cell-free and cell-associated HIV in red blood cell concentrates (RBCC). Cell-free or cell-associated clinical HIV isolates were spiked into RBCC to a final virus concentration of $10 \% \mathrm{v} / \mathrm{v}$ followed by the addition of PEN110 to a final concentration of $0.1 \% \mathrm{v} / \mathrm{v}$ and incubation at $22^{\circ} \mathrm{C}$. PEN110 effectively reduced the infectivity of cell-free HIV $\geq 4.7 \pm 0.12 \log _{10} \mathrm{TCID}_{50} / \mathrm{ml} \pm \mathrm{SD}$ and the infectivity of PBMC-associated HIV $\geq 4.5 \pm 0.44 \log _{10}$ $\mathrm{TCID}_{50} / \mathrm{ml} \pm$ SD under these treatment conditions.

In conclusion, these results show that clinical HIV isolates and primary indicator cells can be successfully and reproducibly used to evaluate and validate the efficacy of HIV inactivation procedures. This system affords quantifiable analysis of HIV inactivation procedures under conditions that most accurately reproduce the complexity and dynamics of in vivo infections by HIV.

\section{SCREENING PLASMA MINIPOOLS FOR PVB19 DNA AND HAV RNA USING LIGHTCYCLER TECHNOLOGY}

\author{
L. Pichl, T. Wöhrl, U. Bauerfeind and M. Köhler \\ Blood Center of the German Red Cross Chapters of NSOB, \\ Institute Springe, Germany, Contact: Ipichl@bsd-nsob.de
}

Background: Human Parvovirus B19 (PVB19) and Hepatits A Virus (HAV) are both non-enveloped viruses and resist to inactivation by physicochemical agents. Transmission by blood and blood products is possible. Screening for PVB19 DNA and HAV RNA has therefore become a quality criterion for fractionation plasma collected from blood donations. For this reason we validated a PCR screening method for plasma minipools on the Roche LightCycler system.

Method: Plasma samples derived from individual donors were pooled (pool size: $\leq 96$ don.). Virus particles were concentrated by centrifugation and nucleic acids were extracted by the QIAamp 96 Virus BioRobot Kit (Qiagen, Hilden, D). PCR analysis was carried out on the LightCycler system with the Parvo B19 LC PCR-Kit and the HAV LC PCR-Kit (Artus, Hamburg, D) because the LightCycler features rapid cycling and real-time monitoring.

Results: The $95 \%$ detection limit of the procedure was determined to 12,997 I.U.WHO PVB19/ml pooled single-donor plasma (approx. 7,700 geq/ml) and 1,000 geq NIBSC97/540 HAV/ml respectively. Specificity was shown by testing 100 pools for PVB19 DNA and HAV RNA. All pools tested negative. Performance qualification of the test algorithm was demonstrated by spiking 2 minipools with a PVB19-positive plasma aliquot and HAV cell culture supernatant. Confirmed positive PCR result for the pool was traced back to the reactive individual donation by subpooling with the $x-y$ intersection approach. Then 300 minipools from routine HCV-PCR testing were screened with the described methods. 11 pools were confirmed reactive for PVB19 with titers of $10^{4}$ I.U.WHO PVB19 $/ \mathrm{ml}$ or higher. None of the pools tested positive for HAV-RNA so far.The turn-around time for centrifugation, nucleic acid extraction and amplification/ detection was about $5 \mathrm{~h}$. Therefore PCR for PVB19 DNA and for HAV RNA could be a release criterion not only for plasma but also for cellular components. Workflow allows screening of 29 minipools (max. 29 x 96 don.) including 3 controls (negative, low positive, high positive) in one single LightCycler run.

Conclusions: Feasibility of screening plasma of minipools derived from single blood donations for PVB19 DNA and HAV RNA was shown. The method is suitable for reducing the viral burden of blood components. 


\section{LONG-TERM EXPERIENCE WITH ANTI-HCV SCREENING}

\section{E. Richter and T. Dengler}

German Red Cross Blood Donation Service Baden-Württemberg, Institute Baden-Baden, Germany

Purpose: Since the introduction of a screening test for hepatitis C antibodies in May 1990 we have screened 1,683,418 donations for anti-HCV. This report gives a summary of the screening and the confirmation testing.

Methods: Ortho HCV ELISA $1^{\text {st }}$ gen. was used until November, 1991; Ortho HCV ELISA $2^{\text {nd }}$ gen. was used until July, 1994; Ortho HCV 3.0 ELISA was used until May 1997; Abbott Prism HCV was used since May, 1997. Confirmation testing was done with Ortho RIBA or Abbott MATRIX (frozen samples from 1990 to 1992 had been confirmed retrospectively after availability of RIBA $2^{\text {nd }}$ gen. test). HCV-RNA NAT was performed with Roche Cobas Amplicor.

\section{Results:}

\begin{tabular}{|c|c|c|c|c|c|c|c|c|c|c|}
\hline \multirow[t]{2}{*}{ Year } & \multirow{2}{*}{\begin{tabular}{|c|} 
Donations \\
tested
\end{tabular}} & \multicolumn{2}{|c|}{$\begin{array}{l}\text { Anti-HCV } \\
\text { Screening }\end{array}$} & \multicolumn{3}{|c|}{ Immunoblot positive } & \multirow{2}{*}{$\begin{array}{c}\text { per } \\
100.000 \\
\end{array}$} & \multirow{2}{*}{$\begin{array}{l}\text { Sero- } \\
\text { conv. }\end{array}$} & \multicolumn{2}{|c|}{ HCV-RNA } \\
\hline & & reactive & $\%$ & m & $\mathbf{f}$ & $\sum$ & & & pos. & in $\%$ \\
\hline 1990 & 89,846 & 913 & 1.02 & 18 & 7 & 25 & 28 & & & \\
\hline 1991 & 147,499 & 1,129 & 0.77 & 18 & 8 & 26 & 18 & (1) & & \\
\hline 1992 & 149,554 & 717 & 0.48 & 39 & 33 & 62 & 41 & (9) & & \\
\hline 1993 & 149,731 & 583 & 0.39 & 47 & 55 & 102 & 68 & (4) & & \\
\hline 1994 & 144,813 & 338 & 0.23 & 16 & 15 & 31 & 21 & $1+(4)$ & & \\
\hline 1995 & 160,119 & 248 & 0.15 & 17 & 15 & 32 & 20 & $1+(2)$ & & \\
\hline 1996 & 160,496 & 271 & 0.17 & 13 & 12 & 25 & 16 & 1 & & \\
\hline 1997 & 161,668 & 329 & 0.20 & 14 & 10 & 24 & 15 & 1 & 18 & 75 \\
\hline 1998 & 172,038 & 453 & 0.26 & 15 & 8 & 23 & 13 & 2 & 18 & 78 \\
\hline 1999 & 172,544 & 367 & 0.21 & 9 & 9 & 18 & 10 & 2 & 14 & 78 \\
\hline 2000 & 175,110 & 352 & 0.20 & 9 & 13 & 22 & 13 & $1 *$ & 16 & 73 \\
\hline$\Sigma$ & $1,683,418$ & 5,700 & 0.34 & 215 & 185 & 390 & 16 & & & 75 \\
\hline
\end{tabular}

\section{CAPACITY OF HEAT TREATMENT IN AQUEOUS SOLUTION TO INACTIVATE NON-ENVELOPED VIRUSES}

\author{
D. Bernhardt, W. Schäfer, S. Mehdi, T. Nowak, T. Weimer, \\ A. Gröner \\ Aventis Behring GmbH, Postbox 1230, D-35002 Marburg, Germany
}

Non-enveloped viruses are regarded as rather resistant to a variety of physical virus inactivation or removal methods compared to enveloped viruses. We demonstrate the effective inactivation of porcine circovirus and other non-enveloped viruses by pasteurisation, i.e. heat treatment in aqueous solution. Porcine circovirus, a small single-stranded DNA virus, is related to TTV, the first known human circovirus which has been found in human blood and faeces. In the absence of an infectivity assay for TTV, porcine circovirus may be used as a model virus for studying the capacity of defined manufacturing steps to inactivate or remove TTV. Pasteurisation kinetics for porcine circovirus were studied using different Aventis Behring products and results are compared with pasteurisation kinetics of other non-enveloped viruses. The data demonstrate that pasteurisation is an effective method for inactivation of a variety of non-enveloped viruses.
Conclusion: We have found a relatively high rate of pseudoseroconversions [NS4 antibody-negative donors with HCV infection, marked in ( )] after the introduction of the second test generation. $5 \mathrm{HCV}$-infected blood transfusion recipients could be identified by looking back from this period. Since introduction of the $2^{\text {nd }}$ gen. tests, no further HCV infection of transfusion recipients could be identified by looking back. Real seroconversions of anti-HCV in our donor population are quite rare. In 2000 the first presero-conversion (window-period) donation was identified (*) after introduction of HCV NAT screening in March 1997. The estimated residual risk of transmission of HCV through blood transfusion, based on the seroconversion rate in our donor population and a residual window period of $<40$ days by anti-HCV and HCV NAT minipool screening, is $<1: 560,000$ [1].

1 Cardoso et al., Transfusion 2000;40:1422.

\section{QUALITY IMPROVEMENT IN DOUBLE-DOSE LEUCODEPLETED PLATELET CONCENTRATE DERIVED FROM HAEMONETIC MCS PLUS VERSION C, THROUGH CONTINUOUS LEUCODEPLETION PROCESS VALIDATION AND IN PROCESS CONTROL}

\author{
J. Seghatchian ${ }^{1}$, P. Krailadsiri ${ }^{1}$, R. Kelly ${ }^{1}$, A. Dransart ${ }^{2}$,
} S. Holme ${ }^{2}$

${ }^{1}$ National Blood Service, UK ${ }^{2}$ Haemonetic Limited, UK and USA

Programming of the Haemonetic MCS + version A for a set number of cycles depends on donor gender, blood volume processed, historical haematocrit and platelet count and previous yield. Using version A protocol we found that it is important to reduce the head height of filtration (from $80 \mathrm{ml} / \mathrm{min}$ to $40 \mathrm{ml} / \mathrm{min}$ ) to reduce the non-compliance with standard (platelet yield $>4.8 \times 10^{11}$ and WBC content $<5 \times 10^{6}$ ) from $3 \%$ to $0.3 \%$. We have also identified six donors who failed 
leucodepletion as the frequency of donations became shorter - the donor leucocytes from these donors are often lighter and lightly settled on buffy coat and easily lifted up during the serge procedure and moreover they are less adhesive and pass through 4 Log filter. In collaboration with manufacturers we developed a version $\mathrm{C}$ programme using continuous filtration system for double-dose production, using an in-house guideline (donor Hct $>0.40$, platelet $>260 \times 10^{9} / \mathrm{L}, 7$ cycles; donor Hct $0.4-0.42$, PLT $>265 \times 10^{9} / \mathrm{L}, 8$ cycles, and donor with Hct $>0.42$ and platelet count $>250 \times 10^{9} / \mathrm{L}, 9$ cycles). Overall, 182 full donations were collected up to now where $98.7 \%$ donations were with inspecification for platelet yield and $100 \%$ were leucodepleted. Concern was expressed as continuous contact with filter can enhance some biological response modifiers. A new protocol was defined to assess the quality of the first and second part of collection in terms of platelet activation marker CD62P, microvesiculation, complement activation cellular injury measured by Annexin V, IL8 and TGF beta as new markers of

\begin{tabular}{|l|l|l|l|}
\hline & $\begin{array}{l}\text { Positive Ab } \\
\text { Screen }\end{array}$ & $\begin{array}{l}\text { Negative Ab } \\
\text { Screen }\end{array}$ & Patients Total \\
\hline negative & 1,701 patients & 69,693 patients & 71,394 patients \\
crossmatches & 2,762 units & 144,644 units & 147,406 units \\
\hline $\begin{array}{l}\text { positive } \\
\text { crossmatches }\end{array}$ & 124 patients & 0 & $\begin{array}{l}124 \text { patients }= \\
0.17 \% 354 \text { units }= \\
0.239 \%\end{array}$ \\
\hline Distribution of the & 1,825 patients & & \\
\hline AIHA & 54 patients & & 54 \\
\hline TRA & 990 patients & & 990 \\
\hline TIA & 781 patients & & 781 \\
\hline
\end{tabular}

Methods: We investigated our protocols from July 1, 1989 to September 1, 1999. In parallel to blood grouping we always performed antibody screening and, if positive, an antibody identification using Capture ${ }^{\circledR} \mathrm{R}$ Screen or ID test (immucor, Atlanta, GA, U.S.A.). We performed the crossmatch using the "classical" tube test with LISS (low ion strength solution) and anti-human globulin. In addition to the crossmatch we repeated antibody screening in a tube. Regarding serological findings we classified the antibodies into transfusion-relevant (TRA), irrelevant (TIA) or autoimmune hemolytic antibodies (AIHA).

\section{Results:}

All crossmatches with the sera of the 69,693 patients without irregular antibodies and the 144,644 units were negative, no serological incompatibility could be detected. In case of the 1,825 patients with irregular antibodies, 124 (6.8\%) showed an incompatible crossmatch result either due to an additional antibody or to a corresponding antigen.

Conclusion: So it seems that crossmatching reduces the risk of incompatibility only in case of irregular red cell antibodies. In case of no red cell antibodies, unnecessary time-consuming crossmatching is a dangerous procedure for patients in emergency situations.

\section{COMPARISON OF THREE DIFFERENT METHODS OF RED CELL ANTIBODY SCREENING AND IDENTIFICATION}

\section{$\underline{\text { R. Stute, A.Patek }}$ \\ Blood Donor Center Saar Pfalz, Saarbrücken, Germany}

\author{
R. Stute, A.Patek \\ Blood Donor Center Saar Pfalz, Saarbrücken, Germany
}

Background: Worldwide type and screen is a very usual method of pretransfusional testing. On the other hand crossmatching is mandatory in Germany. Therefore we reanalyzed our crossmatch protocols of the last ten years to find out how many incompatible reactions we detected. Of special interest was the question if incompatible results were related to positive or negative screening results.
Background: Antibody screening is the most important pretransfusional test. During a period of 18 months we compared the results of three different tests (128 samples), when enough material was available. Otherwise we tested only two methods and compared the results (test $1 /$ test $2 \mathrm{n}=95$, test $1 /$ test 3 $\mathrm{n}=50$ samples).

Methods: We performed antibody screening according to the manufacturer's instructions using 1. Capture ${ }^{\circledR}$ R Ready Screen 
(immucor, Atlanta, GA, U.S.A.). 2. BioVue ${ }^{\circledR}$ (Ortho Clinical Diagnostics, Raritan, U.S.A). 3. The classical tube test using 3 screening cells, LISS and anti-human globulin. If the screening test was positive we immediately performed two or three identification tests.

\section{Results:}

\begin{tabular}{|llll|}
\hline Antibody & Capture & BioVue & Tube Test \\
\hline $\begin{array}{l}\text { Total } 128 \text { test 1 / } \\
\text { test 2 / test 3 }\end{array}$ & 120 & 114 & 91 \\
\hline Missing antibodies & 8 & 14 & 37 \\
\hline Total 95 test 1 / test 2 & 91 & 85 & \\
\hline Missing antibodies & 4 & 10 & \\
\hline Total 50 test 1 / test 3 & 49 & & 30 \\
\hline Missing antibodies & 1 Anti-M & & 20 \\
\hline Finding antibodies & $95.2 \%$ & $89.2 \%$ & $68 \%$ \\
\hline
\end{tabular}

None of the tests finds all antibodies. Capture ${ }^{\circledR}$ detected 95.2\% and missed 3 Anti-Fya, 2 Anti-K, 1 Anti-Jkb, 1 Anti-C, 1 Anti-E, 1 Anti-c, 1 Anti-V, 1 Anti-Cob, 1 Anti-M, 1 AntiLeb. BioVue ${ }^{\circledR}$ detected $89.2 \%$ and missed 4 Anti-Fya, 4 AntiC, 4 Anti-E, 3 Anti-D, 2 Anti-S, 2 Anti-K, 2 Anti-Cw, 1 AntiJka, 1 Anti-Jkb, 1 Anti-c, 1 Anti-N. The tube test found $68 \%$ and missed 57 antibodies.

Conclusion: Only the combination of the Capture ${ }^{\circledR}$ test and the BioVue ${ }^{\circledR}$ covers $100 \%$ of all transfusion-relevant antibodies. Therefore pretransfusional red cell antibody testing needs two independent sensitive screening methods.

\section{NON-SPECIFIC BINDING OF DISEASE-ASSOCIATED PRION PROTEIN TO PLASMINOGEN AND OTHER PROTEINS}

\author{
M. Vey ${ }^{1}$, W. Seyfert-Brandt ${ }^{1}$, E. Vogel1, H. Baron ${ }^{2}$, \\ and A Gröner ${ }^{1}$ \\ ${ }^{1}$ Aventis Behring $\mathrm{GmbH}$, Postfach 1230, \\ D-35002 Marburg, Germany; \\ ${ }^{2}$ Aventis Behring S.A., 46 Quai de la Rapee, \\ F-75601 Paris Cedex 12, France
}

Prion diseases are transmissible, neurodegenerative diseases caused by an infectious protein termed $\mathrm{PrP}^{\mathrm{Sc}}$. $\mathrm{PrP}^{\mathrm{Sc}}$ is hydrophobic and insoluble in non-denaturing detergents with a tendency to stick to various surfaces. A recent report on the binding of $\mathrm{PrP}^{\mathrm{Sc}}$ to plasminogen on magnetic beads in the presence of detergents (Fischer et al., 2000, Nature) has led to the perception that plasminogen might be capable of binding specifically to $\mathrm{PrP}^{\mathrm{Sc}}$ also under physiological conditions. Here we show that not only plasminogen but other proteins as well, such as a monoclonal antibody specific for the T-cell antigen $\mathrm{CD} 3$, bind to $\mathrm{PrP}^{\mathrm{Sc}}$ under the same conditions as plasminogen. In addition, the extent of $\mathrm{PrP}^{\mathrm{Sc}}$ binding seems to be dependent on the detergent used for solubilisation of the scrapie brain homogenate because $\mathrm{PrP}^{\mathrm{Sc}}$ binding to plasminogen is strongly reduced in the presence of sarcosyl. From our own findings and earlier reports on the unusual properties of prions (Prusiner et al., 1981, PNAS), we conclude that binding of $\mathrm{PrP}^{\mathrm{Sc}}$ to proteins such as plasminogen and antibodies is most probably caused by its hydrophobicity and its tendency to aggregate. Therefore, conclusions on the specificity and relevance of $\mathrm{PrP}^{\mathrm{Sc}}$ binding to plasminogen solely based upon capture studies employing these unphysiological, high-detergent conditions need to be carefully reconsidered.

\section{RESULTS OF ROUTINE INTEGRITY TESTING OF TSCD TUBE CONNECTIONS}

\section{W. Boecker, A. Bexte, M. Oehler, G. Walther-Wenke German Red Cross Blood Transfusion Service Nordrhein- Westfalen, Institute Muenster, Germany}

Background: In April 1999 the advisory board of the German Ministry of Health („Arbeitskreis Blut") proposed integrity testing of TSCD tube connections as part of requirements for using this method in blood component preparation.

Material and Methods: Top and bottom blood bag systems of Fresenius Hemocare (T 2814, T 2729, T 2930), Macopharma (LQT $7240 \mathrm{XC}$ ) and other blood bag systems for special preparations were used. There were certificates of conformity for all tubes. Sterile tube connections were made by Terumo $\mathrm{TSCD}^{\circledR} .100 \%$ integrity testing was performed as inprocess control using a tube stripping device test procedure.

Results: 59,961 connections were performed for the preparation of 13,779 blood components: 8,314 pooled, filtered PCs 3,085 pediatric RBCs, 1,328 filtered RBCs, 128 washed, filtered RBCs and 924 special blood preparations. 1 out of 1,249 tube connections turned out to be leak. 46 pooled, filtered PCs and 2 pediatric exchange blood preparations had to be discarded. Inaccuracies were caused by incorrect positioning of tubes in the sealing head, residuals of plastic on the moving parts of the sterile docking device and deviations of tube diameter.

Conclusion: Routine integrity testing of TSCD tube connections is mandatory to identify sources of bacterial contamination. A huge number of data is needed to find leakages. Only well-trained critical co-workers, ongoing maintenance of the devices and the tube stripping device test procedure allow us to gain all benefits of sterile docking in blood banking. 